This is a post-print version of Allan, D. and Duckworth, V. (forthcoming) Voices of Disaffection: Disengaged and disruptive youths or agents of change and self-empowerment? British Journal of Special Education

\title{
Voices of Disaffection: Disengaged and disruptive youths or agents of change and self- empowerment?
}

David Allan,* Faculty of Education, Edge Hill University, England.

Vicky Duckworth, Faculty of Education, Edge Hill University, England.

\begin{abstract}
This article presents findings from research conducted into school disaffection in the north of England. Bourdieu's concept of capital is utilised to explore the perspectives of 14-16-yearold girls undertaking vocational learning as a strategy for re-engagement. Data emanate from semi-structured interviews in which social and linguistic capital in school is identified as a privileged feature of a select few. Thus, within the field of education, capital facilitates student empowerment, whereupon the lack of such can lead to marginalization, disaffection and, subsequently, disengagement. However, voice is presented as a powerful mechanism for challenging the existing inequities of compulsory schooling in England by validating unacknowledged capital, recognising agency, and thus facilitating the self-empowerment of disaffected young people. Schools are encouraged to rethink their political stance to consider the potentially detrimental impact of a discourse that validates the dominant sociocultural capital and empowers those students whose individual dispositions align with institutional practices.
\end{abstract}

Keywords: Bourdieu; student voice; disaffection; alternative learning environments; empowerment 


\section{Introduction}

In recent years, the notion of student voice contributing to teaching and learning has become a growing concern for educational policy across countries such as Australia, Canada, the USA, and New Zealand, as well as in the UK (Hopkins, 2014). Building on the Education Act of 2002, schools and local authorities in England were encouraged to consult with students 'in connection with the taking of decisions which affect them' (DfE, 2014, 2) and this is often seen as an inclusive strategy for increasing student participation (Flutter and Rudduck, 2004) and for addressing marginalisation.

In this paper, we draw on the work of Pierre Bourdieu as a framework for conceptualising the interplay between the structural functioning of a learning environment and the role of student voice in agency. Bourdieu's concept of capital 'acts as a social relation within a system of exchange' (Harker et al. 1990, 1) and it can be identified in many forms, such as social, cultural, and economic. It is thus a valuable commodity for promoting prestige and, as a form of linguistic capital, we conceptualise voice as a significant contributor to this. In the paper, voice is positioned as 'a range of activities that encourage reflection, discussion, dialogue and action' and is concerned with opportunities for 'students to articulate their views and see through appropriate changes' (Fielding, 2004, 199). Therefore, voice is proposed as a strategy for self-empowerment for young people, particularly those marginalised by their schooling, and is thus conceptualised as a mechanism for attaining sociocultural, and linguistic, capital. Through dialogic engagement, wherein student-teacher interactions shape the learning experience, voice becomes a vehicle for validating unacknowledged capital, and thus enables under-privileged students to contribute to policy and practice.

The recognition of student input is mostly a privilege aligned to those students who exhibit the accepted sociocultural capital of the school; the consequence of which can perpetuate inequalities, particularly where some students struggle to engage with the institutional 
discourse. We argue, then, that many young people are being silenced in the classroom as they are seen to lack the sociocultural capital which is often valued by the institution. Tokenistic measures of incorporating voice, however, can result in further marginalization (Mitra, 2008), particularly for those already disengaged students who need to be heard, and this can lead to what Smyth $(2006,283)$ terms 'resistance to learning.' For instance, in situations where students feel they do not hold the necessary capital to compete, insistence on their vocalised participation can result in a failure to capitalise on the potential for inclusion and can, subsequently, lead to further disaffection and disengagement.

We suggest that encouraging marginalised students to speak out can strengthen engagement through a validation of their narrative. Where voice contributes to changes in practice, marginalised students' capital can be legitimated, thus helping to challenge structural inequities that may lead to disaffection. Young people are powerful agents in their own right, yet can, through the structural limitations of schooling (such as not being positioned as active contributors to the teaching and learning process) easily become disempowered. Voice is thus argued as a tool for reconfiguring student-teacher power dynamics.

\section{Voice}

Since the 1990s, the student perspective has become a growing concern for researchers (Garlick, 2008; Hartas, 2011; Baroutsis et al., 2016) yet despite this, policy discussions are 'rarely focused on how to listen to young people and understand their point of view' (Riley et al., 2006, 18), even though some upwardly driven strategies designed to facilitate voice have proven effective for reducing disaffection and for improving the decision-making process (Shallcross et al., 2007). Consequently, voice is often dominated by a select few and its 
absence or 'political injustice' (Mills et al., 2016, 102) can further disempower already marginalised students.

Research suggests that the more decisions students can make, the greater success they will see (Garlick, 2008). Therefore, projects where students actively participate in the construction of lessons, and contribute to the classroom environment - often making decisions with décor and so on - could prove beneficial for re-engagement as previously unacknowledged capital is valued. Cremin et al. $(2011,588)$ investigated the 'voices of pupils who would not normally be part of the school council' in order to illustrate a potential 'contrast with more articulate voices of pupils who are more used to being listened to.' They argue that in some schools a dissonance exists between official and unofficial discourse of engagement and disaffection, whereby addressing student voice is often problematic. Official discourse generated by government policy - 'helps to shape practice' while unofficial discourse illustrates that schools have "neither the time nor the capacity to engage meaningfully with what young people have to say' (Cremin et al., 2011, 597/8). Further, Hancock and Mansfield (2002, 184) argue 'that teachers can disregard children's views and perspectives in practice.' Thus, where disaffected students' voices fail to become officialised - for example, they do not contribute to the school curriculum (Pennacchia et al., 2016) - these young people may experience further marginalization and choose to disengage from learning.

\section{Understanding disengagement}

Since the early 1980s, student disengagement has proven to be a significant policy concern for England - such focus said to have been 'inextricably linked to the collapse of the youth labour market in the late 1970s' (White and Laczik, 2016, 17) - and has remained, at least as an indirect focus, ever since. Drawing on data from the Longitudinal Study of Young People in England, a government report in 2009 presented four categories of engaged/disengaged young people, with around $45 \%$ of students in year 11 (15/16-year-olds) identified as 
disengaged (Ross, 2009). However, while such students often struggle to commit to their schooling, and thus may suffer the consequences of marginalization, many experience tension as they still value education (Graham et al., 2015), thus illustrating an interplay between institutional structures and individual agency. Despite this, disengagement has often been posited through an arguably negative discourse, such as the positioning of school from a default, righteous, stance, and this can result in a deficit construction of some young people (McGregor, 2017). For instance, Snape and Atkinson $(2017,190)$ note that disengagement is 'associated with an increase in disruptive behaviours and truancy.' In this way, agency is acknowledged albeit it is correlated with poor student intellectualising.

Disengagement, however, can be understood as an 'agentic student action' (Allan, 2014, 3) and is arguably a vehicle for students to disconnect from school in order to challenge disempowerment. Such actions function as resistance to schooling's symbolic power and negative labelling which can lead to pathologisation (Duckworth, 2013). Disempowerment, then, is subverted and disengagement acts as empowerment, wherein students engage 'in a scholastic counter-culture that places value on non-academic activities' (Humphrey et al., 2004, 581). In this way, the students can regain an element of power. However, this may lead to a reconceptualization of learning (Allan, 2015) and thus perpetuate school disengagement, whereupon further inequality can arise as the students' actions are problematised (Thompson, 2011).

\section{Methodology}

For the study, semi-structured interviews were conducted with a group of 14-16-year old girls $(n=10)$ undertaking a vocational learning programme. The girls represent a range of schools in the area and have been identified (by their schools) as 'disaffected.' Their allocation to the programme is aimed at re-engagement in learning and they are deemed to be at liberty to choose a setting (tutors note that they express their agency by 'voting with their feet'). The 
data represent the girls' perspectives on learning as they move through a process of disaffection with school - an environment in which they perceive inequitable treatment and what Bourdieu terms symbolic violence as they are 'silenced' - to re-engagement in a vocally liberating alternative setting. A thematic analysis was employed to code the data and themes were identified using an interpretivist paradigm based on Radnor (2002). All names used are pseudonyms.

The programme of study for these girls forms part of a wider, local-authority-led strategy for school re-engagement. It utilises the resources of around 26 privately funded training providers and offers vocational learning opportunities away from the school environment. Some are actual workplaces - salons, garages and so on - while others proffer a work-like environment that merely mimics the workplace but is less formal than a further education college. Tutors are often ex-professionals who have moved into teaching and initially the providers experienced a high staff turnover as they attempted to establish only those individuals with a particular temperament of understanding and empathy. Thus, tutoring staff consists of individuals who have proven success in working with disaffected young people. While this has resulted in a primarily informal environment, with staff who are at liberty to concentrate on re-engagement before qualification attainment, the participants are mostly keen to learn and achieve, and qualifications are taken seriously. Moreover, all the staff have achieved a teaching qualification and consider professional development to be crucial when working with young people. The particular provider in this research specialises in reengagement and hair and beauty training.

According to the schools, students on this programme have previously exhibited active disengagement in a variety of forms, such as long-term truancy, persistent uncooperative behaviour, and lack of participation in learning activities, and many are on the verge of exclusion. Thus, schools deem the students to be in need of intervention and the programme 
functions as an inclusive option aimed at avoiding exclusion; however, the inclusive approach ironically results in the students being educated off site.

\section{Theoretical framework}

This paper employs a Bourdieusian lens to examine the exposition of social processes, and to illustrate the potential for voice to be a mechanism for promoting capital and for tackling inequality, disaffection and marginalization. We thus draw on concepts of capital and field as sensitising tools to explore student voice.

School, with its own rules and regulations, may be deemed a field. Fields are sites of power struggles where cultural capital (in the form of qualifications) can be exchanged. Other forms of cultural capital (such as having knowledge of the arts) can be empowering in social circles and thus legitimate an individual's status within a field. The symbolic power embedded within the field, and legitimate cultural capital, can lead to differential access and advantages. Consequently, education is misdiagnosed as relating to individual natural abilities and effort, rather than in terms of unequal distribution of inherited cultural capital which further privileges certain individuals. Thus, while many individuals' dispositions are legitimated, enabling them to take to the school system and function like 'a fish in water' (Bourdieu and Waquant, 1992, 127), for others this results in marginalisation.

The facilitation of voice is positioned twofold, dependent upon both opportunity and individual confidence. Part of this confidence draws on established literacies, wherein 'institutional literacies' are often viewed as the basis of educational progress and thus deemed to be more important than 'vernacular literacies.' In many ways, 'dominant literacies' equates to linguistic capital, resulting in an othering of vernacular literacies (Duckworth, 2014).

The girls are seen to form experiences, and thus perceptions, through their social interactions. While it is assumed that individual constructs will vary, overall experiences are seen to be clustered and are therefore identified here through a thematic representation of a 
group narrative. Hence, experiences are seen to form an overarching learning journey, and links are made between the girls' social milieux and their educational expectations.

\section{Conceptualising learning and challenging marginalisation}

In this section, the data illustrate how the girls conceptualise learning in each environment and seek to self-empower. Through an exploration of the girls' experiences we present a representative voice, wherein a trajectory of resistance to accepted sociocultural capital, and to the implementation of symbolic violence, can be seen. The data show that all the girls sought to be heard in school but struggled with the way they were treated:

In school, they speak to you like you're a child but here... they're just, I don't know, normal (Hyacinth).

It's like we don't even count...You say something and it's like, 'whatever'. They tell you to do something but half the time they haven't got a clue what they're on about. Mr Murphy was the worst. He'd just say anything to shut us up (Abbey).

What's good about here [the provider] is that they respect you. Moira's really good, she says, 'just give it a try.' She helped me to see what I could do. I used to feel stupid but now I think there are different ways of doing things. Some of the things we learn here really mean something - they're relevant (Isobel).

\section{Disengaging or actively engaging elsewhere?}

The girls talk about frustration at school, due to a lack of voice and recognition, and illustrate disengagement as a retaliatory action to redress the balance of power. In the training provider, they perceive greater opportunities to vocalise concerns and thus their linguistic capital is acknowledged, leading to stronger engagement:

Emily: I didn't really get that much help when I needed it so I'd just flip and walk out the class if no-one come to me straight away.

Interviewer: But here you get the support?

Emily: Yeah. If I can't do something I'll read over it again... but they'll help you (Emily).

When I first came here I said, 'I'm not doing that, it's crap' and Moira said, 'That's OK, you don't have to. What would you like to do?' I couldn't answer her. I wasn't expecting her to say that. Normally it's, 'You have to 
do it so just get on with it.' We sat down and had a chat...she was lovely...I started to feel like someone was interested in me for a change (Abbey).

The girls perceive the training provider tutors to have more time for personal needs and to be more supportive than teachers (perhaps because they feel they are no longer required to compete with the dominant discourse of school); consequently, they exercise greater patience:

Interviewer: What happens if you need help and there's nobody to help you, say, the tutors are busy?

Emily: Erm...I just wait. They come to you when they're ready.

Emily has learned to re-channel her emotions to circumnavigate her frustrations. She has established trust with the tutors and subsequently developed her prestige. Ironically, however, she exercises far less agency in the provider environment. Emily rejected the cultural capital of the school and her former actions contrast with her behaviour in the provider, such as her willingness to re-read her work (a task that her former teachers claim she avoided). As such, she uses these actions to self-empower to gain recognition for her previously unacknowledged linguistic capital. In school, she either refused to accept support or refused to acknowledge its existence as she felt that her agency was challenged:

They think that just because I'm a kid I don't know anything but I know what I want and I know how I like to do things...but they don't listen because they're the teacher and they know best (Emily).

In the provider, she evidences empowerment through a perception of being heard and is thus able to play an active role in her learning. Consequently, her anger subsides:

Interviewer: Why wouldn't you get stressed here [in the provider]?

Emily: Well, I do really but I get more help.

Interviewer: How do they help you? Do they do it for you?

Emily: No, they explain it dead well and then you just get the hang of it yourself.

Emily also appears to re-configure her learner status by reconceptualising learning and education: 
At school...I know it's our education and all that, but you just learn about different subjects. It doesn't really mean anything. But here...this is good...this is what I need to learn to get a job (Emily).

Emily conceptualises learning as an opportunity for personal development but links education with school and negative connotations. This process of metacognition leads to greater self-awareness:

I think coming here has made me grow up a lot. I feel, myself, mature. Being here, I can concentrate on my work but in school I didn't have that (Jade).

The girls suggest that school was a domain of disempowerment and their perceptions of the structural practices of the alternative environment highlight this further. The pressure to accept the existing capital of the school often resulted in further marginalisation but this was challenged through agentic disengagement. For instance, Hyacinth's frustration through being silenced led to her refusal to conform:

Interviewer: What about the work that you do?

Hyacinth: I didn't do it.

\section{Environment-related perceptions}

The girls claim that they became disinterested in school because of a lack of structural constraints that failed to recognise their sociocultural capital:

I was trying to talk to Mr Blacoe about me auntie Joan who runs a hairdressing salon but he wasn't interested. He said, 'Why don't you do something a bit more... ambitious.' I know what it's like to work in a business like that, he doesn't. It's all right him looking down his nose at it but what's he? He's only a teacher. I told me auntie and she said just ignore him. But how can they expect us to have respect for them when they do things like that? (Bryony).

In school, it's all about fitting in and doing what they say but sometimes they're wrong and they [teachers] need to see it (Abbey).

You never get a minute in school. We always seem to be working towards...deadlines. And you have the teachers breathing down your neck... especially that coffee breath. I asked Mr Blacoe if I could work with Jenny on my coursework but he said, 'No, you'll just mess about.' And 
when I asked him if I could do something different he just said we should stick to the topic 'cos 'we haven't got enough time' (Clara).

However, the training provider is seen to facilitate empowerment as voice is accommodated:

They listen to you in here (Fiona).

As such, the girls identify and address their needs, with the subsequent impact of this becoming evident in their further commitment to the provider:

Fiona: My behaviour has improved loads and my attendance is better. I never used to go to school... I'd bunk [truant]. I'm in here every day.

Fiona's experience of disempowerment in school contrasts with her time at the provider. She argues that its informal approach enables her to feel comfortable enough to be critical, whilst also building a rapport with staff:

Moira's [tutor] like my mum. I can tell her anything (Hyacinth).

Consequently, many structural constraints - such as behaviour management - were accepted without question, even when they mirrored the practices of school. In school, conformity is perceived as necessary but the impact of this is a perception that voices become unheard:

Fiona: You go in and they tell you to shut up and get on with it but half the time we don't even know what we're doing. Interviewer: What happens if you tell them? Fiona: They don't listen. They just say 'have a go', but they never explain anything.

Thus, the girls disengage from school to reclaim agency and express a voice in the provider whereupon they shape the curriculum:

We said we wanted to work with clients and do some of the more advanced stuff and they said, 'OK, let's give it a go.' If that was school they'd say, 'Well, we have to follow the guidelines...you're not allowed to do that...you can't just do what you want.' But it's our education (Fiona). 
In this way, the provider is conceptualised as an environment that accepts previously unacknowledged capital and school is further problematised:

They [tutors] recognise us for who we are and they help us to get something out of our learning that we can use. They don't judge us and say, 'You're naughty' or, 'You need to do this.' They get to know us and they help us to learn but they've always said we have a lot of experience already and we know how to work with people. I like that 'cos I feel that they fit in with us (Abbey).

School is perceived to be disempowering due to a lack of recognition of sociocultural capital and thus identity:

I was talking to Abbey once and Mrs Arnold said, 'Bryony, be quiet. Noone's interested in what you got up to last night.' So I said, 'No! Nobody's interested in what we're doing today' and she kicked me out the class. (Bryony).

However, agency and self-empowerment are evident in the narratives as the girls have utilised the provider environment as a critical space to reflect and to develop autonomy:

I've learnt a lot since I've been here. I've been able to step back and think about what I wanna do when I leave. You don't get that in school. I think there's too much pressure on what we have to do, what exams we have to take (Davina).

\section{Discussion}

The girls' narratives illustrate the unacknowledged sociocultural, and linguistic, capital they drew on to resist barriers, such as the institutionalised capital of the school (Reay, 2005) and its subsequent labelling and categorising of social worth (Duckworth, 2013). Their resistance to succumb to the dominant capital has resulted in a defence against the establishment and engagement in counter-scholarly activities that value unacknowledged capital (Humphrey et al., 2004). The girls took ownership of their narratives and their disengagement from school represents a reclamation of agency. Consequently, the girls re-label their experiences as stories of success, wherein they challenge and resist the recognised structural inequalities of school and use voice to self-empower. Thus, the girls reclaim identities that are not 
stigmatised by their inability to acquire the dominant capital; rather, they are celebrated for using linguistic capital and telling their stories situates their 'voice' in the public domain.

\section{Implementing student voice: Cause for concern}

For many students, having a voice can increase self-esteem and motivation, and this can discourage disaffection. Voice can also lead to greater metacognition and autonomy as students reflect on their own contribution to their situation (Allan, 2015). Arguably, establishing opportunities for voice is a mechanism for encouraging learner autonomy, rather than functioning as mere tokenism. However, generating a voice that validly represents students' concerns can be problematic, particularly if a contractual relationship has not been established between the young person and the system.

Garlick (2008) claims that the most effective use of student voice allows for their greater involvement in aspects such as teaching and learning and policy-making. However, listening to students and actively implementing change based on their needs can, and often does, emerge as two separate actions (Cremin et al., 2011). Rudduck and Fielding (2006, 229), for instance, note that 'although the idea of pupil consultation and participation is supported by policy-makers...it is not mandatory and 'fitting it in' is a problem.' Further, Cremin et al. $(2011,587)$ argue, 'Even when voices are heard...headteachers and others may not feel that they have the mandate to act on what they know is in the best interests of the young people in their care.'

Incorporating student voice involves 'not only a minor change in pedagogical practice...but also a 'paradigm shift' in teachers' very identity [whereby] their existing practice is...criticised and redefined as lacking' (Bragg, 2007, 510). Thus, while we argue that voice is a vehicle for reclaiming agency, we wholly acknowledge that implementation is structurally problematic. As such, it requires multi-faceted support at macro level (government, local authorities, and networks of schools working together), meso level (head teachers, teacher 
managers and teachers collaborating), and micro level (teachers working directly with students to listen to the voices of those marginalised by the system). Teachers' beliefs and practices can influence their perceptions of students' abilities, resulting in a typologising of students, such as focusing on whether they can illustrate the recognised capital or not. Therefore, at the micro level voice can act as a mechanism for challenging the reproductive tendencies that these perceptions involve, such as the legitimation of some forms of symbolic capital (Bourdieu, 1991).

\section{What's in it for schools?}

Whilst involving young people in decision-making can reduce disaffection (Hartas, 2011), there is a caveat about 'undue weight' being placed on some views (Flutter and Rudduck, 2004, 2/3), particularly where some are stronger than others (Gunter and Thomson, 2007). Consequently, many marginalised students may remain unheard (Mills et al., 2016). For schools, a collaborative agreement involving students could prove feasible if voice is both valorized and representative of the wider student population. In this way, schools can accommodate need while avoiding the temptation to speak for students (Cook-Sather, 2006, 349), and student voice can contribute to change (Shallcross et al., 2007).

Thus, there is arguably juggling required when listening to students' views, such as validating these views and then implementing action without seemingly disregarding suggestions that do not appear to fit the existing structure. Misinterpreting voice can be disempowering and therefore contribute to disenfranchisement and, subsequently, further disaffection. As such, the need for an authentic and active voice should perhaps consider the implication on future engagement.

Clearly, school is a site where identities and futures are formed, and where strong relationships can impact on attendance and engagement (Vellos and Vadeboncoeur, 2015). However, rather than offering a meritocratic model where everyone is on an equal footing, 
this research suggests that school is often experienced as a site of intergenerational marginalisation (Duckworth, 2013) and social exclusion, and a domain for teacher- and peerlabelling. At a critical time when the participants were becoming more aware of how they fitted into the classroom, self-conscious emotions such as pride, shame and guilt emerged. These girls' experiences, then, highlight a need to prevent the perpetuation of feelings of anxiety, confusion, and worry that some marginalized students experience.

The girls stated that they initially felt concern with learning in an institutional context and on arrival at the training provider they expected to be judged and pathologised by others. They believed that their lack of academic success at school was a reflection on their actual ability and drew a link between what they considered to be poor literacy skills and being childlike. This is perhaps unsurprising when in many aspects of society - particularly officialised sites of learning - learners with low academic achievement are labelled as lacking and therefore deemed less employable. Unfortunately, the dominant discourse that runs through much compulsory education is often constructed on a deficit model which positions learners such as these as deficient in sociocultural capital. Consequently, this norm of educational curricula can lead to social exclusion and greater disaffection as marginalized students' voices are further silenced.

As a retaliatory mechanism, the girls disengage to self-empower. However, while they are empowered in their peer groups, and perhaps in their community, there is still a gulf between community and school status. In the training provider, voice is acknowledged and the students are officially re-empowered as their status is validated with professional adult recognition.

\section{Conclusion}

While listening to students is not a new concept, collaborative implementation requires development as adults need 'to let go of power and to trust in the capacity of young people to 
make responsible decisions' (Baroutsis et al., 2016, 451). Over the last 15 years, student involvement in school improvement has increased, with successful implementation resulting in a gain in the trust of the young person (McIntyre et al., 2005). However, this is often a performative exercise as linguistic capital fails to be evenly distributed and the youth voice is not accorded the same status as that of the adult (Frost and Holden, 2008). Moreover, student input on policy is usually insignificant (Gunter and Thomson, 2007), with opinions 'sought only after significant decisions...have already been made' (Brooker and MacDonald, 1999, 83). Consequently, the present acknowledgement of student voice merely pays lip service to many under-privileged students who do not have the linguistic capital to feel they can air their views. Thus, structures are not in place where voice can contribute to change in educational curricula (Pennacchia et al., 2016) and such learner marginality relates to the dynamics of symbolic violence (Bourdieu, 1991).

Disaffected students, then, are often silenced through symbolic violence and disengagement functions as the reacquisition of agency (Allan, 2014). Implementing a strong student voice can be liberating and can lead to re-engagement in learning through a growth in self-esteem and an emphasis on student value. Such opportunities may include student forums, whereupon voice can be given a critical space within the school and thus validated as a powerful mechanism for addressing marginalisation. However, as already noted, voice needs to be representative of all students.

This research project sought to contest the validity of a marginalised student voice in schools by enabling an opportunity to elicit the perspectives of young girls disaffected with learning. As such, it recognises the value of their literacies which are interwoven with identity and practice and therefore shape interactions. Alternative education can open up a space for an equitable approach where those marginalised by dominant capital experience a level playing field. In England, the compulsory education system would arguably benefit 
from the acknowledgement, and redress, of the historical and contemporary disparities that exist, along with the structural inequalities that many learners experience. A way to address this is for educators and society to recognise, and value, the cultural dimensions the learners bring in order to reconstruct a curriculum that is meaningful to all.

In sum, the school environment is often unsuitable for many students yet developing a space for voice could alleviate this by acknowledging the capital that students use within their community. In this research, voice is seen to empower young disaffected girls, and this is important as they often have a great deal to contribute but feel that they are not in a position to do so (Rudduck and Fielding, 2006). On the whole, all students should feel confident that their voice is an active part of their learning development.

\section{References}

Allan, D. (2014). Dealing with disaffection: The influence of work-based learning on 14-16year-old students' attitudes to school. Empirical Research in Vocational Education and Training, 6(10), 1-18.

Allan, D. (2015). Mediated disaffection and reconfigured subjectivities: The impact of a vocational learning environment on the re-engagement of 14-16-year-olds. International Journal on School Disaffection, 11(2), 45-65.

Bourdieu, P. (1991). Language and symbolic power. Cambridge, MA: Harvard University Press.

Bourdieu, P. \& Waquant, L. (1992). An invitation to reflexive sociology. Chicago: University of Chicago Press.

Bragg, S. (2007). 'But I listen to children anyway!-Teacher perspectives on pupil voice. Educational Action Research, 15(4), 505-518. 
Brooker, R. \& MacDonald, D. (1999). Did we hear you?: Issues of student voice in a curriculum innovation. Journal of Curriculum Studies, 31(1), 83-97.

Cook-Sather, A. (2006). 'Change based on what students say': Preparing teachers for a paradoxical model of leadership. International Journal of Leadership in Education, 9(4), 345358.

Cremin, H., Mason, M. \& Busher, B. (2011). Problematising pupil voice using visual methods: findings from a study of engaged and disaffected pupils in an urban secondary school. British Educational Research Journal, 37(4), 585-603.

DfE [Department for Education]. (2014). Listening to and involving children and young people. DfE-00011-2014. London: DfE.

Duckworth, V. (2013). Learning trajectories, violence and empowerment amongst adult basic skills learners. London: Routledge.

Duckworth, V. (2014). Literacy and transformation. In V. Duckworth \& G. Ade-Ojo (Eds.) Landscapes of specific literacies in contemporary society: Exploring a social model of literacy (pp. 27-46). London: Routledge.

Fielding, M. (2004). Transformative approaches to student voice: Theoretical underpinnings, recalcitrant realities. British Educational Research Journal, 30(2), 295-311.

Flutter, J. \& Rudduck, J. (2004). Consulting pupils: What's in itfor schools? Oxon: Routledge.

Frost, R \& Holden, G. (2008). Student voice and future schools: Building partnerships for student participation. Improving Schools, 11(83), 83-95.

Garlick, S. (2008). Can we hear the student voice? Management in Education, 22(3), 15-18.

Graham, L. J., Van Bergen, P. \& Sweller, N. (2015). 'To educate you to be smart':

Disaffected students and the purpose of school in the (not so clever) 'lucky country'. Journal of Education Policy, 30(2), 237-257. 
Gunter, H. \& Thomson, P. (2007). Learning about student voice. Support for learning, 22(4), $181-188$.

Harker, R., Mahar, C. and Wilkes, C. (1990). An introduction to the work of Bourdieu. London: Macmillan.

Hartas, D. (2011). Young people's participation: Is disaffection another way of having a voice? Educational Psychology in Practice, 27(2), 103-115.

Hopkins, E. A. (2014). Supporting pre-service teachers to enhance the effectiveness of their classroom practice through engaging with the 'voice' of their pupils. Teacher Development, $18(1), 15-28$.

Humphrey, N., Charlton, J. P. \& Newton, I. (2004). The developmental roots of disaffection? Educational Psychology, 24(5), 579-594.

McGregor, G. (2017). Counter-narratives that challenge neo-liberal discourses of schooling 'disengagement': Youth professionals informing the work of teachers. British Journal of Sociology of Education, 38(4), 551-565.

McIntyre, D., Pedder, D. \& Rudduck, J. (2005). Pupil voice: Comfortable and uncomfortable learnings for teachers. Research Papers in Education, 20(2), 149-168.

Mills, M., McGregor, G., Baroutsis, A., Te Riele, K. \& Hayes, D. (2016). Alternative education and social justice: Considering issues of affective and contributive justice. Critical Studies in Education, 57(1), 100-115.

Mitra, D. (2008). Balancing power in communities of practice: An examination of increasing student voice through school-based youth-adult partnerships. Journal of Educational Change, 9(3), 221-242. 
Pennacchia, J., Thomson, P., Mills, M. \& McGregor, G. (2016). Alternative programmes, alternative schools and social justice. Critical Studies in Education, 57(1), 1-5.

Radnor, H. (2002). Researching your professional practice: Doing interpretive research. Milton Keynes: Open University Press.

Reay, D. (2005). Beyond consciousness? The psychic landscape of class? Sociology, 39(5), 911-928.

Riley, K. \& Docking, J. (2004). Voices of disaffected pupils: Implications for policy and practice. British Journal of Educational Studies, 52(2), 166-179.

Riley, K., Ellis, S., Weinstock, W., Tarrant, J. \& Hallmond, S. (2006). Re-engaging disaffected pupils in learning: Insights for policy and practice. Improving Schools, 9(1), 17-31.

Ross, A. (2009). Disengagement from education among 14-16 year olds. London:

Department for Children, Schools and Families.

Rudduck, J. \& Fielding, M. (2006). Student voice and the perils of popularity. Educational Review, 58(2), 219-231.

Shallcross, T., Robinson, J., Pace, P. \& Tamoutseli, K. (2007). The role of students' Voices and their influence on adults in creating more sustainable environments in three schools. Improving Schools, 10(1), 72-85.

Smyth, J. (2006). Educational leadership that fosters 'student voice'. International Journal of Leadership in Education, 9(4), 279-284.

Snape, L. \& Atkinson, C. (2017). Students' views on the effectiveness of motivational interviewing for challenging disaffection. Educational Psychology in Practice, 33(2), 189205.

Thompson, R. (2011). Reclaiming the disengaged? A Bourdieuian analysis of work-based learning for young people in England. Critical Studies in Education, 52(1), 15-28. 
Vellos, R. E. \& Vadeboncoeur, J. A. (2015). Rebuilding attendance practices with youth: The role of social mediation. Educational Studies, 41(1-2), 91-108.

White, C. \& Laczik, A. (2016). Engaging disaffected learners in key stage 4 through workrelated learning in England. Journal of Vocational Education \& Training, 68(1), 17-32. 